Fowler, D. N., E. B. Webb, M. P. Vrtiska, and K. A. Hobson. 2020. Winter carry-over effects on spring body condition driven by agricultural subsidies to Lesser Snow Geese (Anser caerulescens caerulescens). Avian Conservation and Ecology 15(2):21. https://doi.org/10.5751/ ACE-01743-150221

Copyright (C) 2020 by the author(s). Published here under license by the Resilience Alliance.

Research Paper

\title{
Winter carry-over effects on spring body condition driven by agricultural subsidies to Lesser Snow Geese (Anser caerulescens caerulescens)
}

Drew N. Fowler ${ }^{1}$, Elisabeth B. Webb ${ }^{2}$, Mark P. Vrtiska ${ }^{3,4}$ and Keith A. Hobson ${ }^{5}$

${ }^{1}$ Missouri Cooperative Fish and Wildlife Research Unit, University of Missouri, Columbia, Missouri, USA, ${ }^{2}$ U.S. Geological Survey, Missouri Cooperative Fish and Wildlife Research Unit, University of Missouri, Columbia, Missouri, USA, ${ }^{3}$ Nebraska Game and Parks Commission, Lincoln, Nebraska, USA, ${ }^{4}$ University of Nebraska - Lincoln, Lincoln, Nebraska, USA, ${ }^{5}$ Department of Biology, Western University, London, Ontario, Canada

\begin{abstract}
Anthropogenic changes to landscapes associated with intensive agriculture often have deleterious effects on avian abundance. However, some species like the Lesser Snow Goose (Anser caerulescens caerulescens), can benefit from increases in agricultural crops on both wintering and migratory stopover sites. We investigated the influence of winter habitat use on spring body condition in Lesser Snow Goose, a species that has increased in population following expansion into agriculturally based winter habitats. We used stable isotope measurements of four elements $\left(\delta^{2} \mathrm{H}, \delta^{13} \mathrm{C}, \delta^{15} \mathrm{~N}\right.$, and $\left.\delta^{34} \mathrm{~S}\right)$ to determine likely prior winter habitat use of snow geese collected during spring migration across Arkansas, Missouri, and Nebraska in 2016. We evaluated differences in body size, lipid, and protein reserves from individuals with isotope values that suggested winter habitat use in traditional coastal marsh and non-coastal /agriculture habitat. Inferred winter habitat influenced total body lipid levels in snow geese collected during spring migration. Adult and juvenile individuals inferred to have overwintered in coastal marsh $(n=60)$ had, on average, $33.4 \mathrm{~g}(95 \%$ Confidence Interval: 0.4 $\mathrm{g}, 66.4 \mathrm{~g}$ ) less lipid than counterparts wintering in non-coastal / agricultural habitat $(\mathrm{n}=77)$. Waterfowl foods found in marshes typically have low true metabolizable energy values as a consequence of their high fiber content, which likely increases daily consumption rates. Increased energy expenditure related to greater time spent foraging, paired with lower energetic rewards, may result in lower lipid reserves among geese using coastal marsh habitats compared to birds using agricultural landscapes. Consequently, carry-over effects based on winter habitat use could explain variation in lipid reserves among individuals during spring migration and may ultimately explain differential fitness rates or susceptibility to harvest. Our results have implications for the conservation and management of this species as historic wetland landscapes become more intensively converted and used for agricultural purposes.
\end{abstract}

\section{Effets différés de l'hiver sur la condition physique de petites Oies des neiges (Anser caerulescens caerulescens) au printemps en raison des subventions agricoles}

RÉSUMÉ. Les modifications anthropiques de paysages associées à l'intensification de l'agriculture ont souvent des effets délétères sur l'abondance des oiseaux. Cependant, certaines espèces, comme la petite Oie des neiges (Anser caerulescens caerulescens), peuvent bénéficier de l'expansion des cultures agricoles sur les sites d'hivernage et les haltes migratoires. Nous avons étudié l'effet de l'utilisation des habitats d'hiver sur la condition physique au printemps de la petite Oie des neiges, une espèce dont la population a augmenté suite à l'expansion des habitats d'hiver en milieu agricole. Nous avons utilisé des mesures d'isotopes stables de quatre éléments $\left(\delta^{2} \mathrm{H}, \delta^{13} \mathrm{C}\right.$, $\delta^{15} \mathrm{~N}$ et $\delta^{34} \mathrm{~S}$ ) pour déterminer l'utilisation probable d'habitats hivernaux antérieurs d'Oies des neiges collectées pendant la migration printanière en Arkansas, au Missouri et au Nebraska en 2016. Nous avons évalué la différence de taille, de réserves lipidiques et protéiques d'individus ayant des valeurs isotopiques qui suggéraient une utilisation hivernale de marais côtiers traditionnels et de milieux non côtiers/agricoles. L'habitat d'hiver présumé a influé sur le degré de lipides corporels totaux chez les oies collectées pendant la migration printanière. Les individus adultes et juvéniles ayant apparemment hiverné dans un marais côtier $(\mathrm{n}=60)$ avaient en moyenne $33,4 \mathrm{~g}$ (intervalle de confiance à $95 \%: 0,4 \mathrm{~g}, 66,4 \mathrm{~g}$ ) de lipides en moins que leurs congénères ayant hiverné dans un milieu non côtier/ agricole $(\mathrm{n}=77)$. Les ressources alimentaires qu'on trouve dans les marais ont généralement une valeur énergétique métabolisable réelle faible en raison de leur teneur élevée en fibres, ce qui augmente probablement le taux de consommation quotidienne. L'augmentation de la dépense énergétique liée au temps passé à la recherche de nourriture, associée à un apport énergétique plus faible, entraînent sans doute une diminution des réserves lipidiques chez les oies qui utilisent les marais côtiers par rapport aux oies qui utilisent les milieux agricoles. Par conséquent, les effets différés fondés sur l'utilisation des habitats hivernaux pourraient expliquer la variation des réserves lipidiques entre les individus pendant la migration printanière et expliqueraient en fin de compte peut-être les différences de taux d'aptitude ou de vulnérabilité à la récolte. Nos résultats ont des répercussions pour la conservation et la gestion de cette espèce considérant que les paysages historiques de milieux humides sont de plus en plus convertis et utilisés à des fins agricoles.

Key Words: Arctic geese; stable isotopes 


\section{INTRODUCTION}

Conservation and management of migratory birds requires knowledge of migratory connectivity and identification of sites where key nutrients used to fuel migration are acquired (Lindström 1991, Schaub et al. 2008, Webster et al. 2002, Warnock 2010). This is particularly relevant as more and more lands are converted to intensive agriculture. However, while many species have been negatively affected by conversion of natural habitats to cropland (Gibbs et al. 2009, Stanton et al. 2018) some species have been shown to benefit from agricultural expansion (Bennett et al. 2006, Stavert et al. 2018). For example, the North American midcontinent population of Lesser Snow Geese (hereinafter snow geese) has responded positively following expansion into new winter habitats created primarily by rice (Oryza sativa) agriculture in the late $20^{\text {th }}$ century (Abraham et al. 2005, Alisauskas et al. 2011). Although a large proportion of snow geese now overwinter in these agricultural habitats, they also continue to winter in coastal marsh habitats (Jónsson et al. 2014).

Events encountered and effects incurred in one season can impact an individual's fitness in subsequent seasons (Norris 2005, Harrison et al. 2011, Sedinger and Alisauskas 2014). An individual's performance based on lagged processes during a previous season is thus termed a "carry-over effect" (Sedinger and Alisauskas 2014). For example, Black-tailed Godwits (Limosa limosa islandica) that used coastal wintering habitats with highquality food resources arrived at breeding grounds earlier and had better breeding success compared to individuals that overwintered in inland habitats containing lower quality foods (Gunnarsson et al. 2005). Similarly, hen mallards (Anas platyrhnchos) with larger nutrient reserves measured in late spring had higher nesting propensity, nest initiation, and clutch size (Devries et al. 2008). Collectively, individual carry-over effects often scale up to influence population level processes, such as annual recruitment, and are termed "cross-seasonal effects" (Fox et al. 2005, Sedinger and Alisauskas 2014). This phenomenon of carry-over and cross-seasonal effects results from inherent variation among individuals in their ability to access or use resources (Harrison et al. 2011) and thus can increase fitness heterogeneity.

We used stable isotope techniques to determine prior winter habitat use (Hénaux et al. 2012) among snow geese collected during spring migration and assessed the ability of winter origin data to explain variation in spring body condition and body size of collected individuals. Historically, snow geese overwintered in coastal marshes in Texas and Louisiana through the 1960s, which was thought to regulate population size due to high mortality associated with the energetic expenditure of foraging in this habitat type (Alisauskas et al. 1988, Francis et al. 1992, Ankney 1996). After snow geese expanded into additional winter habitat types, Alisauskas et al. (1988) reported lower true metabolizable energy values in coastal marsh diet items, relative to agricultural diet items such as rice and corn (Zea mays), suggesting that body condition of individuals using different habitat types may vary prior to spring migration. Therefore, if carry-over effects during spring migration are incurred due to winter habitat use, we hypothesized that individuals using coastal marsh habitats would have reduced spring body condition (primarily lower lipids) compared to individuals using agricultural habitats. Further, snow geese overwintering in coastal marshes have previously been documented as being larger bodied compared to individuals overwintering in rice or corn predominant landscapes (Alisauskas 1998, Jónsson 2005). Hence, we expected to find similar trends in body size among spring collected individuals based on winter habitat classification. Snow geese are within a guild of herbivorous waterfowl that have adapted positively to global modifications in land use resulting from agricultural production (Fox and Abraham 2017, Fox and Madsen 2017), though many bird species have responded negatively (Wretenberg et al. 2006). As the global footprint of agriculture continues to expand at a rate faster than any other time period within the last 50 years (Laurance et al. 2014), our research on snow geese may serve as one example for a continuing larger global phenomenon that impacts bird guilds differently.

\section{METHODS}

\section{Collection of spring individuals to assess body condition and winter habitat use}

We collected snow geese across east-central Arkansas and southeast Missouri, northwest Missouri, and southeastern Nebraska, USA, during spring migration from 11 February - 7 March $2016(n=173)$. These regions were characterized by intensive agricultural production of rice, corn, and winter wheat (Triticumaestivum) and typify landscape characteristics that snow geese use during spring migration (Abraham et al. 2005). Collection areas were considered key snow goose staging areas during spring migration and band recovery and harvest estimates indicated a greater proportion of snow geese harvested in these states compared to other states in the Mississippi and Central flyways (Webb et al. 2010, Alisauskas et al. 2011, Kruse and Fronczak 2014). Therefore, we collected birds in these states to ensure a heterogeneous sample range of nutrient reserves among sex and age classes representative of snow goose populations during spring migration. We obtained individuals harvested over decoys from participants in the Light Goose Conservation Order as well as those that were collected using jump shooting techniques (Fowler et al. 2018).

For individuals collected during spring, we aged snow geese as juvenile or after hatch-year (FY or AHY, respectively) using plumage characteristics and foot color and recorded sex based on reproductive organs during dissections (Baldassarre 2014). We weighed thawed individuals to the nearest $0.5 \mathrm{~g}$ with an electronic scale. To assess body size, we measured head, culmen, and total tarsus length with digital calipers to the nearest $0.1 \mathrm{~mm}$, and measured body length and un-flattened wing chord to the nearest mm using a measuring board (Dzubin and Cooch 1992, Fowler et al. 2018). We used the correlation matrix from these five morphometrics to develop a univariate index of body size based on loadings from the first component of a principle components analysis.

\section{Dissection and chemical analyses of geese}

A complete description of methods for dissection and chemical analyses of geese are detailed in Fowler et al. (2018), but in brief, we shaved individuals of their feathers to estimate muscular and cardiac protein and weighed and removed ingesta-contents to achieve an ingesta-free body mass ( $\mathrm{g}$ ). To infer winter habitat use, we extracted $1 \mathrm{~cm}^{3}$ sample of bicep muscle from one wing for 
isotopic analysis (details below). We ground individual carcasses through an industrial meat grinder and then dried a subsample to a constant mass. Subsequently, we submitted pulverized homogenate samples to the University of Missouri Agricultural Experiment Station Chemical Laboratory for proximate analysis of crude lipid and protein following standardized procedures (Alisauskas 2002, Horwitz 2006). Total body lipids and protein were then scaled to body size as described in Alisauskas (2002) and Fowler et al. (2018).

\section{Inference of winter habitat use}

To infer likely winter habitat use (and by proxy, broad geographic wintering origin) in spring migratory geese, we followed a similar approach described by Hénaux et al. (2012) where stable isotope values were determined in bicep muscle tissue of geese collected at known reference winter habitat types to serve as a basis for assignment. No direct experimental studies have been conducted on the elemental turnover of bicep muscle tissue in snow geese. However, we calculated turnover rates of muscle in snow geese using the relationship derived by Martinez del Rio and Carleton (2012) where turnover rate is related to proportional change in body mass raised to the power of -0.25 . We used this relationship and data from captive studies of canvasback (Aythya valisineria) with mean mass of 1,248 $\mathrm{g}$ and a whole blood half-life of 23 days (Haramis et al. 2001). Assuming muscle tissue has a similar turnover rate to whole blood, we estimated muscle tissue isotope values in snow geese represent habitats approximately 52 days (i.e. two half-life turnover rates) prior to sampling (Haramis et al. 2001). Hénaux et al. (2012) analyzed $\delta^{2} \mathrm{H}, \delta^{13} \mathrm{C}$, and $\delta^{15} \mathrm{~N}$ values in bicep muscle tissue and found strong predictive power based on the combined use of all three isotopes for classification. Additionally, Hénaux et al. (2012) suggested future work assess the use of $\delta^{34} \mathrm{~S}$ as a fourth possible isotope to distinguish between coastal and non-coastal habitats because of typically higher sulfate $\delta^{34} \mathrm{~S}$ values in marine food webs (Hobson 1999). Therefore, we collected reference bicep muscle tissue from wings of snow geese harvested during winter at known discrete geographic locations and habitat types and analyzed each sample for $\delta^{2} \mathrm{H}, \delta^{13} \mathrm{C}, \delta^{15} \mathrm{~N}$, and $\delta^{34} \mathrm{~S}$ values. We collected wings of loafing or feeding adult and juvenile snow geese shot by hunters in, or in close proximity to, coastal marshes of Texas (Brazoria County; 29 06' N 95 $19^{\prime} \mathrm{W}$ ) and Louisiana (Cameron Parish; $29^{\circ} 44^{\prime} \mathrm{N} 92^{\circ} 50^{\prime} \mathrm{W}$ ) as well as in predominant agricultural landscapes in southeastern Arkansas within the Mississippi

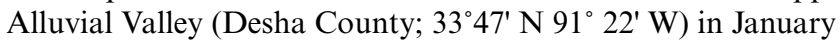
2016 and 2017. In Desha county, agricultural production was the predominate landcover type and consisted primarily of soybeans (Glycine max), rice, corn, and winter wheat (USDA 2017). Because snow geese were present in coastal and agricultural habitats from November to January (Jónsson and Afton 2006), we expected individuals collected as references were in equilibrium with local food resources (Hénaux et al. 2012). Unfortunately, samples collected in 2016 were lost due to spoiling from an undetected freezer outage during storage so only individuals collected in $2017(n=46)$ served as reference samples.

We removed lipids from all bicep muscles (reference and unknown samples) using an overnight chloroform:methanol (2:1 $v / v$ ) solvent soaking and rinse. Stable hydrogen isotope measurements were performed on $\mathrm{H}_{2}$ gas derived from high- temperature $\left(1,450^{\circ} \mathrm{C}\right)$ flash pyrolysis of $1.5 \pm 0.25 \mathrm{mg}$ muscle subsamples (packed in silver capsules) using continuous-flow isotope-ratio mass spectrometry. Pyrolytic combustion was on a reactor with glassy carbon chips under helium flow in a PyroCube (Hanau, Germany - www.elementar.de) elemental analyzer interfaced with an Isoprime (Manchester, UK) continuous flow isotope ratio mass spectrometer (IRMS). Estimates of the nonexchangeable $\mathrm{H}$ in samples were derived from two keratin hydrogen-isotope reference materials (CNS: -197\%; KHS: $-54.1 \%$ ) following the comparative equilibration approach of Wasssenaar and Hobson (2003). All $\delta^{2} \mathrm{H}$ results are reported for nonexchangeable $\mathrm{H}$ in delta notation, in units of per mil (\%o), and normalized on the Vienna Standard Mean Ocean Water (VSMOW) standard scale. Based on within-run replicate $(n=7)$ measurements of keratin reference materials, we estimated measurement error (SD) to be $\sim \pm 1.4 \%$.

For $\delta^{13} \mathrm{C}$ and $\delta^{15} \mathrm{~N}$ analyses, $2.0 \pm 0.5 \mathrm{mg}$ of muscle material (packed in tin capsules) was combusted online using a PDZ Europa ANCA-GSL elemental analyzer (Sercon Ltd., Crewe Cheshire, UK). The resulting $\mathrm{CO}_{2}$ was separated by gas chromatography (GC) and introduced into a PDZ Europa 20-20 isotope-ratio mass-spectrometer via an open split and compared to a pure $\mathrm{CO}_{2}$ or $\mathrm{N}_{2}$ reference gas. Stable nitrogen $\left({ }^{15} \mathrm{~N} /{ }^{14} \mathrm{~N}\right)$ and carbon $\left({ }^{13} \mathrm{C} /{ }^{12} \mathrm{C}\right)$ isotope ratios were expressed in $\delta$ notation, as parts per thousand (\%o) deviation from the primary standards, atmospheric AIR and Vienna Pee Dee Belemnite (VPDB). Using previously calibrated internal laboratory standards (bovine liver: $\delta^{13} \mathrm{C}=-21.7 \%$, $\delta^{15} \mathrm{~N}=7.7 \%$ and nylon $6: \delta^{13} \mathrm{C}=-27.7 \%, \delta^{15} \mathrm{~N}$ $=-10.5 \%$ ) within-run $(n=5)$, precision for $\delta^{15} \mathrm{~N}$ and $\delta^{13} \mathrm{C}$ measurements was $\sim \pm 0.05 \%$.

For $\delta^{34} \mathrm{~S}$ analyses, $3.50 \pm 0.5 \mathrm{mg}$ of muscle material (packed in tin capsules) was combusted in a Vario Pyro Cube (Elementar, Langenselbold, Germany - www.elementar.de) elemental analyzer and the resulting $\mathrm{SO}_{2}$ gas was introduced into SerCon 20-20 IRMS Stable sulfur $\left({ }^{34} \mathrm{~S} /{ }^{32} \mathrm{~S}\right)$ was expressed in $\delta$ notation, as parts per thousand (\%o) deviation from the Vienna Canyon Diablo Triolite (VCDT) standard. Taurine $\left(\delta^{34} \mathrm{~S}=-2.5 \%\right.$ ) and cysteine $\left(\delta^{34} \mathrm{~S}=34.2 \%\right.$ ) were used as secondary isotopic reference materials for calibration and had within run precision measurements of $\pm 0.3 \%$ o $(n=19)$ and $\pm 0.2 \%$ o $(n=12)$, respectively. All samples were analyzed at the University of California - Davis Stable Isotope Facility.

To infer whether muscle tissues from different collection areas were isotopically distinct, we calculated mean muscle stable isotope values from each collection state and ran a multiple analysis of variance (MANOVA; $\alpha<0.05$ ). Muscle values for all four isotopes were normally distributed (Shapiro test: all $P^{\prime} \mathrm{s}>$ 0.05 ) and homoscedastic (Levene's test: all $P^{\prime} \mathrm{s}>0.05$ ). We initially tested for differences in tissue stable isotope values between adult and juvenile individuals using a MANOVA and found no effect of age on stable isotope values $\left(F_{4,39}=1.06, P=0.392\right)$. Therefore, we used both adult and juvenile reference samples to build linear discriminant functions. Because we had less certainty regarding the utility of all four stable isotope values to accurately classify winter habitat use, we assessed the performance of a suite of linear discriminant functions that used a combination of isotopes as predictors. We considered models sets of two different classification types. First, we evaluated models that predicted a 
spatially explicit response to the respective states we collected reference samples in (i.e. Arkansas, Louisiana and Texas). Secondly, we built binary response models that predicted overwinter origins to coastal marsh habitat type (using Louisiana and Texas reference samples) or non-coastal / agricultural habitat (using Arkansas reference samples). We used the MASS package (Venables and Ripley 2002) in of Program R (Version, 3.3.3, R Core Team 2018) to derive all linear discriminate functions.

We assessed the performance of candidate linear discriminate function in two ways. First, we assessed the overall model accuracy of assignment for the discriminant function based on $\mathrm{K}$-fold cross validation $(K=10)$. Secondly, we assessed the discrete group accuracy, precision, and recall of the discriminant function based on a confusion matrix of the true class and predicted class of the individuals resulting from cross validation (James et al. 2013). We determined the strength of the individual model based on the collective metrics of accuracy, precision, and recall.

\section{Winter habitat use assignment}

We classified likely inferred winter habitat use of spring collected individuals using the best performing linear discriminant function (hereafter referred to as "Winter Habitat LDF"). Following prediction, we retained only those individuals with posterior probability of assignment that was $\geq 0.80$ based on visual assessment of the probability density function of classified individuals. The determination for this cutoff is partially subjective but provides a means to retain the majority of individuals, based on natural breaks in the density function (Beatty et al. 2014), classified with high probabilities while removing individuals that had lower origin probability certainty despite classification.

For snow geese classified as "non-coastal /agricultural", we further examined their muscle $\delta^{13} \mathrm{C}$ values in order to estimate the percent $\mathrm{C} 3$ vs $\mathrm{C} 4$ plants in their diet. Plants with a $\mathrm{C} 4$ photosynthetic pathway occur naturally as grasses in more arid regions but in agriculture are overwhelmingly represented by corn, sorghum and millet, whereas many coastal wetlands plants (e.g., Scirpus americanus) and rice have C3 photosynthetic pathways. The large isotopic difference between $\mathrm{C} 3$ plants (mean $\delta^{13} \mathrm{C}$ $=-27 \%$ ) and $\mathrm{C} 4$ plants (mean $\delta^{13} \mathrm{C}=-12 \%$ ) allows the estimation of the relative contribution of $\mathrm{C} 4$ plants to a consumer that otherwise feeds in a largely C3 biome (e.g., Werner et al. 2016, 2020). In our study, we assumed this estimate would translate primarily into the relative consumption of spilled/waste corn in agricultural habitats by geese sampled in spring. We assumed a trophic enrichment factor associated with plant to goose muscle as $+0.9 \%$ as summarized by Caut et al. 2009 (see also Werner et al. 2016). Applying this factor, we estimated a goose with $100 \%$ $\mathrm{C} 3$ diet to have a muscle $\delta^{13} \mathrm{C}$ value of $-26.1 \%$ and one consuming $100 \%$ corn to have a muscle $\delta^{13} \mathrm{C}$ value of $-11.1 \%$ so, an individual with a muscle $\delta^{13} \mathrm{C}$ value of $\mathrm{X}$, would have a relative (percent) proportion of $\mathrm{C} 4$ diet of $((26.1+\mathrm{X}) / 15) * 100$. Using this approach, we assumed any bird with a negative $\mathrm{C} 4$ contribution to be $100 \% \mathrm{C} 3$ or $0 \% \mathrm{C} 4$. To understand potential relationships between $\mathrm{C} 4$ contribution and body condition as well as body size we calculated Spearman's rank correlation coefficients using the base package in Program R.

\section{Model Fitting}

To determine the influence of winter habitat use on spring body condition and body size, we built an individual general linear mixed model to separately describe variation in size adjusted total body lipids, total body protein, and body size based on selected explanatory variables of interest. We formulated the body condition model as

$$
\begin{aligned}
& \text { Condition }= \beta_{0}+\beta_{1} *[\text { Sex }]+\beta_{2} *[\text { Age }]+\beta_{3} *[\text { Habitat Use }]+ \\
& \varepsilon_{\text {Date }} \text { Hatitat Use } \\
&+\varepsilon_{\text {Harvest Type }}
\end{aligned}
$$

where $\beta_{0}$ is the intercept, $\beta_{1} \beta_{2}$ and $\beta_{3}$ are regression coefficients describing the linear relationship between size adjusted body condition (lipids or protein) and sex, age, and classified winter habitat use, and $\varepsilon_{\text {Date*Habitat Use }}$ is random interactive effect between collection date and classified winter habitat use, and $\varepsilon_{\text {Harvest Type }}$ is a random effect of collection method of harvest (hunter decoy shot or jump shot).

To evaluate if body size differed among individuals classified to different wintering habitats, we modeled variation in body size as

$$
\begin{aligned}
\text { Body Size }= & \beta_{0}+\beta_{1} *[\text { Sex }]+\beta_{2} *[\text { Age }]+ \\
& \beta_{3} *[\text { Winter Habitat }]+\varepsilon_{D}
\end{aligned}
$$

where $\beta_{0}$ is the intercept, $\beta_{1} \beta_{2}$ and $\beta_{3}$ are regression coefficients describing the linear relationship between body size (univariate PC1) and sex, age, and classified winter habitat, and $\varepsilon_{D}$ is a random effect of collection date.

We analyzed general linear models using the base package of Program R and used the lme4 package for Program R (Bates et al. 2014) to formulate mixed-effects models, deriving coefficient estimates using restricted maximum likelihood. We assessed goodness of fit by calculating conditional and marginal $\mathrm{R}^{2}$ values (Nakagawa and Schielzeth 2013) with the r.squared GLMM function in the MuMIn package for Program R (Barton 2017). We considered covariates significant when 95\% confidence intervals did not overlap zero $(\alpha=0.05)$.

\section{RESULTS}

\section{Stable isotope values from reference winter habitats and classification model performance}

Results from our multivariate analysis of variance (MANOVA) indicated overall differences $(F=7.10, \mathrm{df}=8$ and $76, P<0.001)$ in reference bicep muscle tissue isotope values among states (Table 1). While $\delta^{2} \mathrm{H}_{m}, \delta^{13} \mathrm{C}_{m}$, and $\delta^{34} \mathrm{~S}_{m}$ differed among collection states $\left(\delta^{2} \mathrm{H}_{m}: F=14.08, \mathrm{df}^{m}=2\right.$ and $43, P<0.001 ; \delta^{13} \mathrm{C}_{m}: F=12.35$, df $=2$ and $43, P<0.001 ; \delta^{34} \mathrm{~S}_{m}: F=34.05$, df $=2$ and $\left.43, P<0.001\right)$, less variation in $\delta^{15} \mathrm{~N}_{m}$ was detected $(F=2.77$, df $=2$ and $43, P=$ 0.073). Similarly, when reference tissues were grouped by habitat type (coastal marsh or non-coastal / agriculture), $\delta^{2} \mathrm{H}_{m}, \delta^{13} \mathrm{C}_{m}$, and $\delta^{34} \mathrm{~S}_{m}$ differed between habitat types $\left(\delta^{2} \mathrm{H}_{m}: F=28.8\right.$, df $=1$ and $44, P<0.001 ; \delta^{13} \mathrm{C}_{m}: F=18.87, \mathrm{df}=1$ and $44, P<0.001$; $\delta^{34} \mathrm{~S}_{m}: F=51.8, \mathrm{df}=1$ and $\left.44, P<0.001\right)$, but $\delta^{15} \mathrm{~N}_{m}$ values did not differ $(F=0.00, \mathrm{df}=1$ and $44, P=0.984)$ (Table 1$)$.

We evaluated predictive performance of ten candidate linear discriminant functions derived from our reference bicep muscle 
Table 1. Mean and standard error of stable hydrogen $\left(\delta^{2} H\right)$, carbon $\left(\delta^{13} \mathrm{C}\right)$, nitrogen $\left(\delta^{15} \mathrm{~N}\right)$, and sulfur $\left(\delta^{34} \mathrm{~S}\right)$ isotope values in reference bicep muscle tissue from adult and juvenile Lesser Snow Geese collected in 2017 coastal marsh (Texas Coast; Louisiana Coast) and non-coastal/ agricultural habitat (Arkansas MAV). MAV $=$ Mississippi Alluvial Valley.

\begin{tabular}{|c|c|c|c|c|c|}
\hline Sampling Region & Sampling Dates & $\delta^{2} \mathrm{H}(\% 0)$ & $\delta^{13} \mathrm{C}(\%)$ & $\delta^{15} \mathrm{~N}(\% 0)$ & $\delta^{34} \mathrm{~S}(\% 0)$ \\
\hline $\begin{array}{l}\text { Arkansas MAV } \\
(n=13)\end{array}$ & 3-5 January & $-159.98(2.46)^{a}$ & $-21.45(0.52)^{\mathrm{a}}$ & $7.32(0.19)^{\mathrm{a}}$ & $-2.46(0.35)^{\mathrm{a}}$ \\
\hline $\begin{array}{l}\text { Texas Coast } \\
(n=13)\end{array}$ & 1-5 January & $-144.95(2.26)^{b}$ & $-22.87(0.34)^{b}$ & $7.79(0.18)^{\mathrm{a}}$ & $1.34(0.49)^{b}$ \\
\hline $\begin{array}{l}\text { Louisiana Coast } \\
(n=20)\end{array}$ & 18 January - 8 February & $-144.72(2.01)^{b}$ & $-23.90(0.24)^{b}$ & $7.02(0.26)^{\mathrm{a}}$ & $3.33(0.49)^{\mathrm{c}}$ \\
\hline \multicolumn{6}{|l|}{ Habitat Grouping } \\
\hline $\begin{array}{l}\text { Non-coastal /Agriculture } \\
(n=13)\end{array}$ & 3-5 January & $-159.98(2.46)^{\mathrm{a}}$ & $-21.45(0.52)^{\mathrm{a}}$ & $7.32(0.19)^{\mathrm{a}}$ & $-2.46(0.35)^{\mathrm{a}}$ \\
\hline $\begin{array}{l}\text { Coastal Marsh } \\
(n=33)\end{array}$ & 1 January - 8 February & $-144.81(1.48)^{b}$ & $-23.49(0.21)^{b}$ & $7.32(0.18)^{\mathrm{a}}$ & $2.55(0.41)^{b}$ \\
\hline
\end{tabular}

tissue samples. Six candidate models discretely classified individuals to their state of collection, while four models classified individuals to the coastal or non-coastal / agricultural habitat types. Discriminant functions that classified individuals to habitat type were more accurate than those classifying individuals to the state of collection, as frequent misclassification occurred between Louisiana and Texas (Table 2). Our most accurate function used $\delta^{13} \mathrm{C}_{m}, \delta^{15} \mathrm{~N}_{m}$, and $\delta^{34} \mathrm{~S}_{m}$ to discriminate between habitat types and had an overall model accuracy of $93.5 \%$, which was $19.6 \%$ more accurate than the top discriminant function classifying individuals to state origins (Table 3 ).

Table 2. Candidate linear discriminant models built for classifying state level winter geographic origins, or habitat type, based on stable hydrogen $\left(\delta^{2} \mathrm{H}\right)$, carbon $\left(\delta^{13} \mathrm{C}\right)$, nitrogen $\left(\delta^{15} \mathrm{~N}\right)$, and sulfur $\left(\delta^{34} \mathrm{~S}\right)$ isotope values from reference bicep muscle tissue in Lesser Snow Geese $(n=46)$ collected from known locations in January 2017. Model accuracy was assessed using $\mathrm{k}$-fold $(\mathrm{k}=10)$ cross validation.

\begin{tabular}{lllc}
\hline \hline Model & Discrete Group & Function Predictors & $\begin{array}{c}\text { Overall Model } \\
\text { Accuracy }\end{array}$ \\
\hline 1 & State $^{\dagger}$ & $\sim \delta^{13} \mathrm{C}+\delta^{34} \mathrm{~S}$ & $56.5 \%$ \\
2 & State & $\sim \delta^{15} \mathrm{~N}$ & $50.0 \%$ \\
3 & State & $\sim \delta^{13} \mathrm{C}+\delta^{15} \mathrm{~N}$ & $54.3 \%$ \\
4 & State & $\sim \delta^{2} \mathrm{H}+\delta^{13} \mathrm{C}+\delta^{15} \mathrm{~N}$ & $65.2 \%$ \\
5 & State & $\sim \delta^{2} \mathrm{H}+\delta^{13} \mathrm{C}+\delta^{15} \mathrm{~N}+\delta^{34} \mathrm{~S}$ & $73.9 \%$ \\
6 & State & $\sim \delta^{13} \mathrm{C}+\delta^{15} \mathrm{~N}+\delta^{34} \mathrm{~S}$ & $73.9 \%$ \\
7 & Habitat Type & $\sim \delta^{2} \mathrm{H}+\delta^{13} \mathrm{C}+\delta^{15} \mathrm{~N}$ & $84.8 \%$ \\
8 & Habitat Type & $\sim \delta^{2} \mathrm{H}+\delta^{13} \mathrm{C}+\delta^{34} \mathrm{~S}$ & $91.3 \%$ \\
9 & Habitat Type & $\sim \delta^{13} \mathrm{C}+\delta^{15} \mathrm{~N}+\delta^{34} \mathrm{~S}$ & $93.5 \%$ \\
10 & Habitat Type & $\sim \delta^{2} \mathrm{H}+\delta^{13} \mathrm{C}+\delta^{15} \mathrm{~N}+\delta^{34} \mathrm{~S}$ & $91.3 \%$ \\
\hline${ }^{\dagger}$ Arkansas, Louisiana, and Texas & \\
${ }^{\dagger}$ Coastal marsh and non-coastal/agriculture habitat &
\end{tabular}

Because of the strong performance of the top classification model (containing $\delta^{13} \mathrm{C}_{m}, \delta^{15} \mathrm{~N}_{m}$, and $\delta^{34} \mathrm{~S}_{m}$ ), we used this discriminant function as our Winter Habitat LDF to classify adult and juvenile individuals $(n=137)$ collected during spring migration based on their winter habitat use. Based on the distribution of probability frequency in posterior probabilities of winter habitat origin classification (Fig. 1), we retained only those individuals with an
$80 \%$, or greater, posterior probability. Using this threshold, we classified 60 individuals to coastal habitat and 77 to non-coastal / agricultural habitat, resulting in 137 individuals with inferred winter habitat use for general linear mixed model analysis (Fig. 2).

Fig. 1. Probability density functions of Lesser Snow Geese $(n=$ 173) assigned to discrete winter habitat types using the "Winter Habitat LDF" linear discriminant function. Lesser Snow Geese were collected during spring migration in Arkansas, Missouri, and Nebraska February - March 2016. Individuals with a posterior probability $\geq 0.80$ (red vertical line) were kept $(\mathrm{n}=$ 137) for analysis to evaluate the influence of winter habitat type on spring body condition and overall body size.
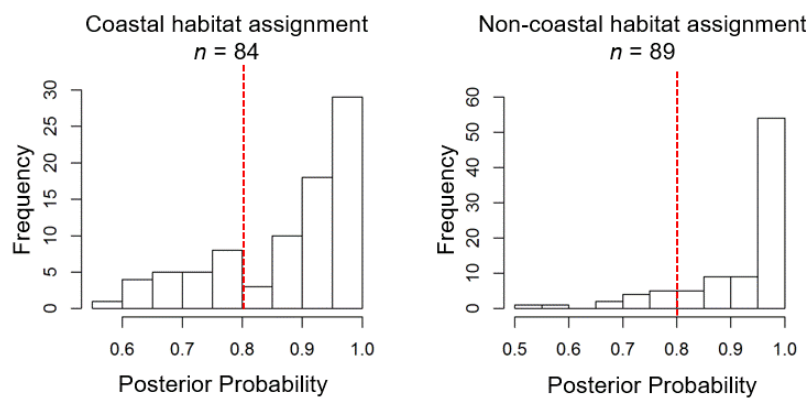

\section{Body condition of spring migrants classified to winter habitat categories}

Lipid content in snow geese was influenced by prior winter habitat use and age classes, but not by sex (Table 4). Individuals classified as overwintering in coastal marsh habitats had $33.4 \mathrm{~g}(95 \% \mathrm{CI}$ : $0.4 \mathrm{~g}, 66.4 \mathrm{~g}$ ) less lipids at the time of collection during spring migration compared to individuals classified as overwintering in rice-based habitats. Additionally, juveniles had $53.4 \mathrm{~g}(95 \% \mathrm{CI}$ : $30.4 \mathrm{~g}, 76.4 \mathrm{~g})$ more lipids than adults. Our model explained approximately $43 \%$ of the overall variation in the data, with the random interactive effect of Julian date of collection and classified winter habitat use and the random effect of harvest collection type accounting for $13 \%$ of the explained variation ( marginal R-squared $=0.20$; conditional R-squared $=0.43$; Table $4)$. 
Table 3. Comparison in model performance between top linear discriminant models when classifying state origins versus habitat types using stable isotope values (carbon $\left(\delta^{13} \mathrm{C}\right)$, nitrogen $\left(\delta^{15} \mathrm{~N}\right)$, and sulfur $\left(\delta^{34} \mathrm{~S}\right)$ derived from reference bicep muscle tissue of Lesser Snow Geese collected in January 2017.

\begin{tabular}{|c|c|c|c|c|c|}
\hline \multirow[t]{2}{*}{ Full model } & \multicolumn{3}{|c|}{$\begin{array}{c}\text { State Origins Model } \\
\text { State } \sim \delta^{13} \mathrm{C}+\delta^{15} N+\delta^{34} \mathrm{~S}\end{array}$} & \multicolumn{2}{|c|}{$\begin{array}{l}\text { Habitat Type Model } \\
\text { Habitat Type } \delta^{13} \mathrm{C}+\delta^{15} \mathrm{~N}+\delta^{34} \mathrm{~S}\end{array}$} \\
\hline & $\begin{array}{l}\text { Arkansas } \\
(n=13)\end{array}$ & $\begin{array}{l}\text { Louisiana } \\
(n=13)\end{array}$ & $\begin{array}{l}\text { Texas } \\
(n=20)\end{array}$ & $\begin{array}{l}\text { Coastal Marsh Habitat } \\
\qquad(n=33)\end{array}$ & $\begin{array}{c}\text { Non-coastal / Agricultural } \\
\text { Habitat } \\
(n=13)\end{array}$ \\
\hline Recall & $92.3 \%$ & $70.0 \%$ & $61.5 \%$ & $93.9 \%$ & $92.3 \%$ \\
\hline Precision & $85.7 \%$ & $82.4 \%$ & $53.3 \%$ & $96.9 \%$ & $85.7 \%$ \\
\hline Accuracy & $93.5 \%$ & $80.4 \%$ & $73.9 \%$ & $93.5 \%$ & $93.5 \%$ \\
\hline
\end{tabular}

Fig. 2. Stable carbon $\left(\delta^{13} \mathrm{C}\right)$, nitrogen $\left(\delta^{15} \mathrm{~N}\right)$, and sulfur $\left(\delta^{34} \mathrm{~S}\right)$ isotope values of Lesser Snow Goose bicep muscle tissue from individuals harvested during spring migration February March 2016. Spring migrants of unknown origin were classified to either coastal marsh habitats (red) or non-coastal / agricultural habitats (blue) using a linear discriminant function derived from reference samples from known habitat types in coastal Texas, coastal Louisiana, and east central Arkansas. Ellipsoids represent the expected distribution of the 75th quartile of observations sampled from a bivariate normal distribution.

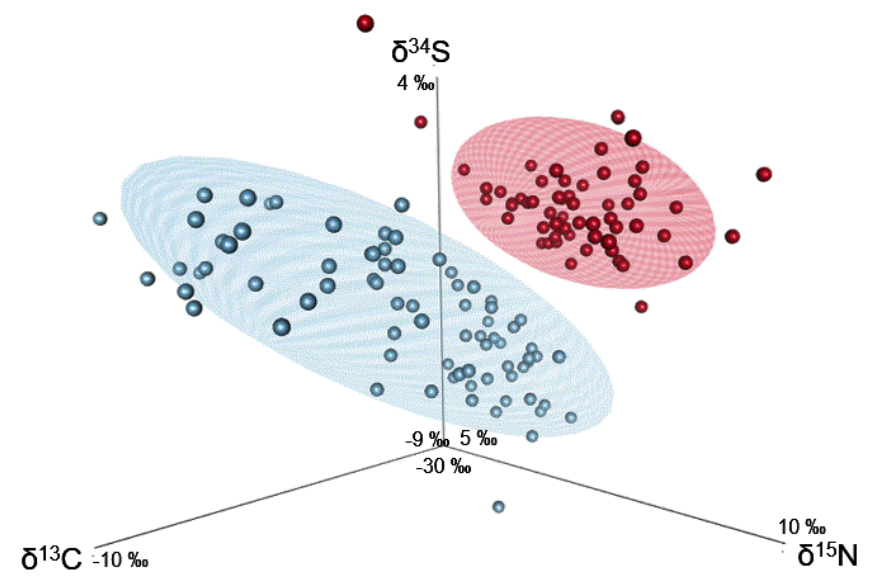

Winter habitat use did not influence protein content, but protein content differed by age and sex (Table 4). Adult individuals had $13.2 \mathrm{~g}$ (95\% CI: $2.6 \mathrm{~g}, 23.8 \mathrm{~g})$ more protein relative to juveniles, while females had $11.5 \mathrm{~g}(1.9 \mathrm{~g}, 21.2 \mathrm{~g})$ less protein compared to males. This model explained approximately $11 \%$ of the overall variation in the data, with the random interactive effect of collection date and classified winter habitat use as well the random effect of harvest collection type accounting for approximately $2 \%$ of the explained variation (marginal R-squared $=0.09$; conditional R-squared $=0.11$; Table 4 ).

Similarly, habitat was not a significant predictor of body size. Rather, sex and age explain variation in body size data (Table 4). Adult geese had 1.10 loading units $(95 \%$ CI: 0.49, 1.71) larger body size than juveniles, while females had 1.15 loading units (95\% CI: $0.60,1.72)$ smaller body size than males. The model including sex and age explained approximately $18 \%$ of the overall variation in the data, with the random interactive effect of Julian date of collection accounting for $0 \%$ of the explained variation ( marginal R-squared $=0.18$; conditional R-squared $=0.18$; Table 4).

Among individuals inferred to non-coastal / agricultural habitat winter use, 36 individuals had $0-25 \% \mathrm{C} 4$ contributions, 20 had 26-50\% C4 contributions, 18 had 51-75\% C4 contributions, and 3 had C4 contributions greater than $75 \%$. Estimates of Spearman's rho were not significant for relationships between $\mathrm{C} 4$ contributions and total protein reserves (rho $=-0.075, P=0.52$ ) and between $\mathrm{C} 4$ contributions and the first principle component of body size (rho $=-0.074, P=0.52$ ). However, increasing $\mathrm{C} 4$ contributions was positively correlated with total body lipids (rho $=0.46, P<0.001 ;$ Fig 3 ).

Fig. 3. Relationship between $\mathrm{C} 4$ dietary integration and total body protein (left), first principle component of body size (center), and total body lipid reserves (right) in Lesser Snow Geese $(n=77)$ collected during spring migration February March 2016 in Arkansas, Missouri, and Nebraska inferred to have used non-coastal / agricultural habitats over winter. R represents Spearman's ranked correlation coefficient. Shown are model estimates (black line) and associated 95\% confidence intervals (shaded area), along with raw data (black dots).
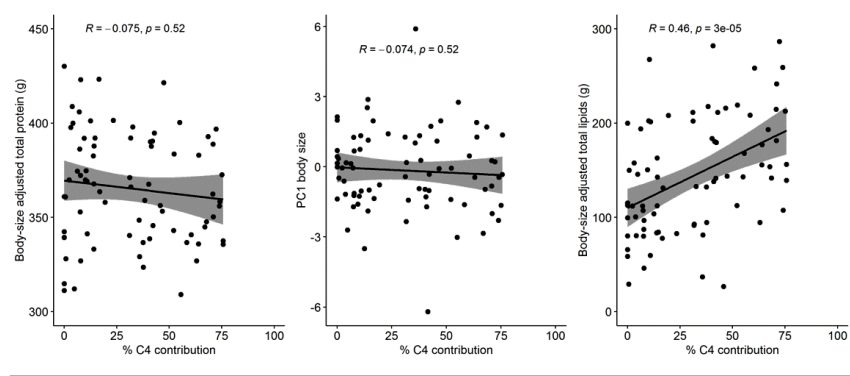

\section{DISCUSSION}

Our study evaluated the influence of winter habitat use on spring body condition during migration, as well as variation in individual body size, of a long-distance migrant waterfowl species using isotope ecology to infer winter habitat use. Our ability to classify 
Table 4. Results of general linear mixed models explaining variation in lipid content ( $\mathrm{g}$ ), protein content (g), and univariate index of body size of Lesser Snow Geese $(n=137)$ with predicted winter habitat origin collected in Arkansas, Missouri, and Nebraska during the spring migration in February - March 2016. Predictor variables included sex (male or female), age (juvenile or adult), winter habitat type (Coastal Marsh, Non-coastal / Agriculture), the random effect for harvest type (decoy or jump shot), and the random effect for Julian date of collection. CI = confidence interval, NA = not applicable.

\begin{tabular}{|c|c|c|c|c|c|c|}
\hline & \multicolumn{2}{|c|}{ Lipid Model } & \multicolumn{2}{|c|}{ Protein Model } & \multicolumn{2}{|c|}{ Body Size Model } \\
\hline & Estimate & $95 \% \mathrm{CI}$ & Estimate & $95 \% \mathrm{CI}$ & Estimate & $95 \% \mathrm{CI}$ \\
\hline$(\text { Intercept })^{\dagger}$ & $106.39^{*}$ & \pm 43.23 & $367.99^{*}$ & \pm 7.60 & $-0.47^{*}$ & \pm 0.44 \\
\hline Age (Juvenile) & $53.43^{*}$ & \pm 23.44 & $-13.23^{*}$ & \pm 10.37 & $-1.17^{*}$ & \pm 0.60 \\
\hline Sex (Male) & -6.40 & \pm 18.62 & $11.56^{*}$ & \pm 9.52 & $1.14^{*}$ & \pm 0.55 \\
\hline Winter Habitat (Non-coastal) & $33.39^{*}$ & \pm 30.73 & -3.63 & \pm 8.86 & 0.31 & \pm 0.51 \\
\hline Marginal $\mathrm{R}^{2}$ & \multicolumn{2}{|r|}{0.20} & \multicolumn{2}{|r|}{0.09} & \multicolumn{2}{|r|}{0.18} \\
\hline Conditional $\mathrm{R}^{2}$ & \multicolumn{2}{|r|}{0.43} & \multicolumn{2}{|r|}{0.11} & \multicolumn{2}{|r|}{0.18} \\
\hline Variance: Julian Date x Winter Habitat (Intercept) & \multicolumn{2}{|c|}{554.72} & \multicolumn{2}{|c|}{16.72} & \multicolumn{2}{|r|}{ NA } \\
\hline Variance: Harvest Type (Intercept) & \multicolumn{2}{|c|}{492.22} & \multicolumn{2}{|r|}{0.00} & \multicolumn{2}{|r|}{ NA } \\
\hline Variance: Julian Data (Intercept) & \multicolumn{2}{|c|}{ NA } & \multicolumn{2}{|r|}{ NA } & \multicolumn{2}{|r|}{0.00} \\
\hline Variance: Residual & \multicolumn{2}{|c|}{2524.38} & \multicolumn{2}{|c|}{680.37} & \multicolumn{2}{|r|}{2.33} \\
\hline Number of Observations & \multicolumn{2}{|c|}{137} & \multicolumn{2}{|r|}{137} & \multicolumn{2}{|r|}{137} \\
\hline
\end{tabular}

${ }^{\dagger}$ Intercept referenced on adult female geese classified as using coastal marsh habitat

$* \mathrm{P} \leq 0.05$

individuals to coastal or non-coastal/agricultural habitat relied on a suite of three stable isotope values $\left(\delta^{13} \mathrm{C}, \delta^{15} \mathrm{~N}\right.$, and $\left.\delta^{34} \mathrm{~S}\right)$ assessed in bicep muscle tissue of migrant snow geese. This particular combination of stable isotopes performed strongly in model cross-validation among nine other candidate models. Though $\delta^{15} \mathrm{~N}$ values only marginally differed $(P=0.07)$ between reference groups, inclusion of $\delta^{15} \mathrm{~N}$ as a third isotope served to enhance the characterization and state-space segregation of wintering habitats. In contrast, while $\delta^{2} \mathrm{H}_{m}$ values were distinct among state collection sites representing different geographic locations, we elected not to use $\delta^{2} \mathrm{H}_{m}$ in our Winter Habitat LDF. This decision resulted from the inability to develop a discriminant function based on reference samples collected in the same year as spring migrants due to a freezer outage (referenced in Methods). Values of $\delta^{2} \mathrm{H}$ have potential for inter-annual variability associated with annual variation in amounts and timing of precipitation that influence $\delta^{2} \mathrm{H}$ values (Hobson et al. 2012). Further, while $\delta^{2} \mathrm{H}$ expresses a strong latitudinal gradient in meteoric waters, $\delta^{2} \mathrm{H}$ values from marine water are more constant across latitude and can therefore result in $\delta^{2} \mathrm{H}$ values that are inconsistent with patterns found in samples influenced solely by meteoric water (Hobson et al. 2000, Lott et al. 2003). Therefore, we used only $\delta^{13} \mathrm{C}, \delta^{15} \mathrm{~N}$, and $\delta^{34} \mathrm{~S}$ because the mechanisms that influence differences in values are less variable across years (Hénaux et al. 2012).

However, our Winter Habitat LDF classified individuals discretely between two broad habitat types but was derived from a limited scope of available reference samples, particularly noncoastal/agricultural habitats. It is likely that our reference samples collected in Arkansas do not fully represent the entire range of isotopic variation found in all non-coastal / agricultural habitats. For example, some snow geese may overwinter exclusively in landscapes where corn agriculture dominates (Alisauskas 1998) resulting in a different isotopic composition from our reference set where rice was a predominant food source. We suspect that some individuals in our study classified to non-coastal / agricultural habitat may have overwintered in corn habitat, as some $\delta^{13} \mathrm{C}$ values were higher than expected for $\mathrm{C} 3$ photosynthetic plants, such as rice (Alisauskas and Hobson 1993, Hobson 1999). Indeed, our partitioning of \% C4 contribution within those individuals assigned to non-coastal / agricultural habitat revealed a range of $\mathrm{C} 4$ dietary integration, indicating that our binary assignment method classified diverse agricultural crops within a single category (Fig. 3). Nonetheless, individuals classified to coastal marsh and non-coastal/agricultural habitats were distinct in their isotopic distribution (Fig. 2), particularly because of the inclusion of $\delta^{34} \mathrm{~S}_{m}$ which is a unique signature indicating the proximity to coastal marsh systems (Peterson and Fry 1987, Hobson 1999, Hénaux et al. 2012). So though we were not able to collect reference samples from multiple spatially explicit agricultural habitats that geese could have overwintered in, we believe samples collected in Arkansas typify agricultural food types available to geese in other agricultural settings and as a result serve as a useful reference set to discriminate against unique isotope values that indicate coastal habitats .

We found that spring body condition can be partially explained as a carry-over effect from winter habitat use. Alisauskas et al. (1988) suggested that individuals using different winter habitats begin spring migration with varying body condition. Our research indicates that variation in spring body condition likely still occurs, and that further, geese using coastal marsh habitats during winter maintain lower overall lipid reserves during spring migration, at least during the sampling period of our study. Consequently, differences in lipid reserves between individuals using distinct winter habitats could in part explain heterogeneous body condition among individuals during spring migration. Further, the impact of these individual carry-over effects could translate to cross-seasonal population effects that may explain individual variation in natural mortality or harvest susceptibility or influence heterogeneous reproductive potential (Ankney and MacInnes 1978, Sedinger et al. 2011, Sedinger and Alisauskas 2014). 
We found that geese inferred to have predominately used noncoastal / agriculturally based winter habitats had higher lipid reserves than geese inferred to have over wintered in traditional coastal marsh habitats. It is possible that coastal and non-coastal geese collected in our study had differential lipid reserves because of variability in energetic costs associated with different migration lengths leading up to the time of collection. However, unless our sample was comprised of birds collected directly upon arrival from their wintering habitat (which we doubt given the timing of our sampling), geese would have had an opportunity to replenish some lipids and thus we suggest our results represents a persistent carry-over effect. Lipid reserves are an important fuel source for waterfowl during winter and spring migration and are primarily catabolized through carbohydrate rich diet items (Jenni and Jennieiermann 1998, McWilliams et al. 2004). Alisauskas et al. (1988) found that coastal marsh diet items such as tubers and rhizomes had lower metabolizable energy estimates compared to rice or corn habitats, meaning that marsh diet items provide less gross energy available to produce lipids. Waterfowl foods found in marshes typically have low metabolizable energy values as a consequence of their high fiber content, which requires increased daily consumption rates by waterfowl and likely results in a greater proportion of time allocated to foraging (Alisauskas et al. 1988, Gauthier et al. 1988). Increased energy expenditure related to greater time spent foraging, paired with lower energetic diet items, may result in lower lipid reserves among geese using coastal marsh habitats compared to birds using landscapes containing rice or other diet items found in agricultural landscapes (Jónsson and Afton 2006). Though our study evaluated differences in lipid reserves broadly between coastal and non-coastal / agricultural habitats, the fact that we found a positive relationship between C4 dietary integration and overall lipid content suggests that there is finer scale heterogeneity in body condition among geese who primarily use different agricultural food sources during winter.

Research conducted concurrently with ours showed that snow geese overwintering in southeast Arkansas did not gain lipids but rather slowly lost them (Massey et al. 2020). This pattern mirrors historic lipid reserve loss observed in geese overwintering along the Texas coast (Hobaugh 1985). The fact that our study reflects higher lipid levels in spring from geese who overwintered in agricultural landscapes could be the result of either different rates of lipid loss between the two habitats or the ability to minimize lipid loss accumulated in the fall by "short-stopping" migration (i.e., Arkansas Mississippi Alluvial Valley). Nonetheless, our study suggests that the ecological consequences of winter foraging habitats and subsequent body condition carry over into spring migration. Although it is likely that all geese eventually use some form of agricultural waste products during spring migration, geese that overwinter in these same habitats may have much more physiological flexibility to potentially skip stopover sites or spend less time at stopover sites compared to geese wintering in coastal marshes and could confer some benefit to future life history events.

Total body protein of spring collected geese did not differ between individuals classified to coastal marsh or non-coastal / agricultural winter habitat types. Though some agricultural food types, like rice, provide a substantially greater fraction of available protein compared to coastal marsh habitats, coastal marsh habitats still provide sufficient protein resources to meet daily existence demands (Alisauskas et al. 1988). While protein reserves are an essential component of structural function in migration, carrying excess protein is an energetic cost to migration (Jenni and Jenni-Eiermann 1998) so similarities in protein levels among individuals that overwintered in different habitat types may be a shared strategy in protein accumulation.

Though previous studies have found individuals wintering in traditional coastal marshes to be generally larger bodied, particularly in bill morphology (Alisauskas 1998, Jónsson 2005), we did not observe differences in body size, inferred by a univariate index (PC1). Alisauskas (1998) suggested that winter range expansion beyond coastal marsh systems facilitated phenotypic selection towards smaller size morphs that could maintain comparable survival rates by implementing grazing or pecking strategies compared to grubbing strategies observed in geese foraging in marshes. Jónsson (2005) and Jónsson et al. (2014) assessed whether snow geese using coastal marshes in Louisiana were a distinct subpopulation that differed from snow geese using agricultural habitats, such as rice, in adjacent lands that previously were coastal prairie. Jónsson (2005) found that although geese using rice habitats were generally smaller than coastal marsh geese, there was notable intraseasonal movement of individuals between the two habitats, leading Jónsson et al. (2014) to conclude that geese using coastal marshes were not a distinct subpopulation. One possible explanation for our finding of similar body size across winter habitat types could come from our methodological approach of classifying spring migrants to either coastal marsh or non-coastal / agricultural habitats. Our Winter Habitat LDF function relied on distinct differences in sulfur isotope values $\left(\delta^{34} \mathrm{~S}_{m}\right)$ found between reference samples collected in the two habitat types. As expected, values of $\delta^{34} \mathrm{~S}_{m}$ were greater for birds collected either in or within close proximity to coastal marshes in Texas and Louisiana. Given the movement of individuals between habitat types reported by Jónsson et al. (2014), it is possible that a significant proportion of our spring migrants classified to coastal marsh systems were individuals who were in close proximity to coastal systems (resulting in higher $\delta^{34} \mathrm{~S}_{m}$ ) but moved frequently into adjacent rice agricultural systems. If this were the case, it is more reasonable to expect these individuals to be of similar body size as those classified to noncoastal / agricultural habitats (referenced by samples collected in Arkansas) which would allow greater flexibility to exploit both habitat types.

\section{Conservation Implications}

Our study indicates that snow goose body condition during spring migration is influenced by previous winter habitat use. Specifically, our results indicate that snow geese wintering in coastal marsh habitat have lower lipid reserves in early spring migration. This finding is consistent with previous studies and reviews that identify the carry-over impact of relative habitat quality on later life history events (Sedinger et al. 2011, Harrison et al. 2011, Sedinger and Alisauskas 2014). Thus, snow geese who primarily use coastal marsh habitat types may have a greater probability of natural mortality (Morrison et al. 2007). Our study design was not equipped to evaluate if breeding productivity was related to differential winter habitat quality. Yet, if coastal marsh habitat use results in reduced body condition into spring migration then it is possible that these trends continue to remain 
in reduced body condition leading up to rapid follicular development and nesting (Ankney and MacInnes 1978, Alisauskas 2002), resulting in lower breeding propensity or fecundity (Sedinger et al. 2011). Thus, future studies could consider evaluating the carry-over impacts of different winter habitat use and resulting body condition on individuals throughout the full annual cycle.

Since 1997, snow geese have been designated as an overabundant species (Batt 1997) due, in large part, to explosive population growth associated with winter range expansion outside of the historical coastal marsh habitats (Hobaugh 1985, Abraham et al. 2005). The Light Goose Conservation Order has allowed unlimited spring take of snow geese since 1999 via liberal hunting regulations and accommodations. However, this initiative to reduce population size via reductions in overall adult survival rates has not been successful, largely due to insufficient harvest rates (Alisauskas et al. 2011, Calvert et al. 2017) and potentially, harvest bias towards poorer conditioned individuals (Fowler et al. 2020). Attempts to actively manage the midcontinent population of snow geese have proved challenging (Leafloor et al. 2012) and our study indicates that snow geese continue to benefit from agricultural subsidies in wintering habitats and that the resulting increased lipid reserves transcend winter into spring migrations, potentially through cross-seasonal effects. Although coastal marsh habitats provide micronutrients not found in agricultural systems (Alisauskas et al. 1988), the abundance of agricultural habitats distributed throughout the migration corridor has facilitated improved energetics through increased availability of food items readily catabolized into lipids. The wide scale availability of agricultural resources throughout major portions of the spring migratory flyway may contribute to the observed increase in survival rates of light geese (Wilson et al. 2016).

Responses to this article can be read online at: https://www.ace-eco.org/issues/responses.php/1743

\section{Acknowledgments:}

We thank K. Kraai, L. Naylor, E. Massey, A. Raedeke, and J. Whittaker for their assistance in providing sample specimens and are grateful to A. Engel, H. Johnson, K. Marre, J. Piercefield, and $B$. Woodall who assisted with data collection and sample processing. Jeff Firman provided laboratory assistance and Geoff Koehler performed CNS isotope analyses at the Environment Canada Stable Isotope Laboratory in Saskatoon, SK. We thank all the participants in the LGCO who submitted birds for our study. We thank B. Dugger, $R$. Alisauskas and an anonymous reviewer for their comments on an earlier version of this manuscript. The Missouri Cooperative Fish and Wildlife Research Unit is jointly sponsored by the Missouri Department of Conservation, the University of Missouri, the U.S. Fish and Wildlife Service, the U.S. Geological Survey, and the Wildlife Management Institute. Any use of trade, firm, or product names is for descriptive purposes only and does not imply endorsement by the U.S. Government. Funding statement: Funding for this project was provided by the Nebraska Game and Parks Commission through the United States Fish and Wildlife Service's
Sportfish and Wildlife Restoration Program and by Ducks Unlimited Canada's Institute for Wetland and Waterfowl Research. Ethics statement: All lesser snow geese collected were labeled and frozen until processing and were collected in accordance with the United States Fish and Wildlife Service scientific collection permit number MB47969B-1, Arkansas state permit number 102320141, Missouri state permit number 16217, Nebraska state permit number 535, South Dakota state permit numbers 1 and 5, and University of Missouri Animal Care and Use Committee permit number 8191. Author contributions: D.N.F and E. B.W formulated research questions; E. B.W and M.P.V. supervised research; D.N.F and M.P.V collected data; D.N.F and K.A.H analyzed the data; D. N.F, E.B.W, M.P.V, and K.A.H wrote this manuscript.

\section{LITERATURE CITED}

Abraham, K. F., R. L. Jefferies, and R. T. Alisauskas. 2005. The dynamics of landscape change and snow geese in mid-continent North America. Global Change Biology 11:841-855. https://doi. org/10.1111/j.1365-2486.2005.00943.x

Alisauskas, R. T. 1998. Winter range expansion and relationships between landscape and morphometrics of midcontinent lesser snow geese. The Auk 115:851-862. https://doi.org/10.2307/4089504

Alisauskas, R. T. 2002. Arctic climate, spring nutrition, and recruitment in midcontinent lesser snow geese. Journal of Wildlife Management 66:181-193. https://doi.org/10.2307/3802884

Alisauskas, R. T., C. D. Ankney, and E. E. Klaas. 1988. Winter diets and nutrition of midcontinental lesser snow geese. Journal of Wildlife Management 52:403-414. https://doi.org/10.2307/3801581

Alisauskas, R. T., and K. A. Hobson. 1993. Determination of Lesser Snow Goose Diets and Winter Distribution Using Stable Isotope Analysis. Journal of Wildlife Management 57:49-54. https://doi.org/10.2307/3808999

Alisauskas, R. T., R. F. Rockwell, K. W. Dufour, E. G. Cooch, G. Zimmerman, K. L. Drake, J. O. Leafloor, T. J. Moser, and E. T. Reed. 2011. Harvest, survival, and abundance of midcontinent lesser snow geese relative to population reduction efforts. Wildlife Monographs 179:1-42. https://doi.org/10.1002/wmon.5

Ankney, C. D. 1996. An embarrassment of riches : Too many geese. Journal of Wildlife Management 60:217-223. https://doi. org/10.2307/3802219

Ankney, C. D., and C. D. MacInnes. 1978. Nutrient Reserves and Reproductive Performance of Female Lesser Snow Geese. The Auk 95:459-471.

Baldassarre, G. A. 2014. Ducks, geese, and swans of North America. Volume 1.John Hopkins University Press, Baltimore, Maryland, USA.

Bartoń, K. 2017. MuMIn: multi-model inference. R package version 1.40.0.

Bates, D., M. Mächler, B. Bolker, and S. Walker. 2014. Fitting linear mixed-effects models using lme4. arXiv preprint arXiv:1406.5823. 
Avian Conservation and Ecology 15(2): 21

Batt, B. 1997. Arctic ecosystems in peril: Report of the Arctic Goose Habitat Working Group. U.S Fish and Wildlife Service, Washington, D.C. and Canadian Wildlife Service, Ottawa, Ontario.

Bennett, A. F., J. Q. Radford, and A. Haslem. 2006. Properties of land mosaics: implications for nature conservation in agricultural environments. Biological Conservation 133:250-264. https://doi. org/10.1016/j.biocon.2006.06.008

Calvert, A. M., R. T. Alisauskas, and G. C. White. 2017. Annual survival and seasonal hunting mortality of midcontinent snow geese. Journal of Wildlife Management 81:1009-1020. https://doi. org/10.1002/jwmg.21277

Caut, S., E. Angulo and F. Courchamp. 2009. Variation in discrimination factors $(\Delta 15 \mathrm{~N}$ and $\Delta 13 \mathrm{C})$ : the effect of diet isotopic values and applications for diet reconstruction. Journal of Applied Ecology 46: 443-453. https://doi.org/https://doi.org/10.1111/ j.1365-2664.2009.01620.x

Devries, J. H., R. W. Brook, D. W. Howerter, and M. G. Anderson. 2008. Effects of spring body condition and age on reproduction in mallards. The Auk 125:618-628. https://doi.org/10.1525/ auk.2008.07055

Dzubin, A., and E. Cooch. 1992. Measurements of geese: general field methods. California Waterfowl Association, Sacramento, California.

Fowler, D. N., K. J. Kuechle, B. A. Woodall, M. P. Vrtiska, and E. B. Webb. 2018. Evaluating indices of lipid and protein content in lesser snow and Ross's geese during spring migration. Wildlife Society Bulletin 42:295-303. https://doi.org/10.1002/wsb.867

Fox, A. D., and K. F. Abraham. 2017. Why geese benefit from the transition from natural vegetation to agriculture. Ambio 46:188-197. https://doi.org/10.1007/s13280-016-0879-1

Fox, A. D., and J. Madsen. 2017. Threatened species to superabundance: The unexpected international implications of successful goose conservation. Ambio 46:179-187. https://doi. org/10.1007/s13280-016-0878-2

Fox, A. D., J. Madsen, H. Boyd, E. Kuijken, D. W. Norriss, I. M. Tombre, and D. A. Stroud. 2005. Effects of agricultural change on abundance, fitness components and distribution of two arcticnesting goose populations. Global Change Biology 11:881-893. https://doi.org/10.1111/j.1365-2486.2005.00941.x

Francis, C., M. Richards, F. Cooke, and R. Rockwell. 1992. Longterm changes in survival rates of lesser snow geese. Ecology 73:1346-1362. https://doi.org/10.2307/1940681

Gauthier, G., Y. Bédard, and J. Bédard. 1988. Habitat use and activity budgets of greater snow geese in spring. Journal of Wildlife Management 52:191-201. https://doi.org/10.2307/3801222

Gibbs, K. E., R. L. Mackey, and D. J. Currie. 2009. Human land use, agriculture, pesticides and losses of imperiled species. Diversity and Distributions 15:242-253. https://doi.org/10.1111/ j.1472-4642.2008.00543.x

Gunnarsson, T. G., J. A. Gill, J. Newton, P. M. Potts, and W. J. Sutherland. 2005. Seasonal matching of habitat quality and fitness in a migratory bird. Proceedings of the Royal Society of
London B: Biological Sciences 272:2319-2323. https://doi. org/10.1098/rspb.2005.3214

Haramis, G. M., D. G. Jorde, S. A. Macko, J. L. Walker, and W. H. Karasov. 2001. Stable-isotope analysis of Canvasback winter diet in upper Chesapeake Bay. The Auk 118:1008-1017. https:// doi.org/10.1093/auk/118.4.1008

Harrison, X. A., J. D. Blount, R. Inger, D. R. Norris, and S. Bearhop. 2011. Carry-over effects as drivers of fitness differences in animals. Journal of Animal Ecology 80:4-18. https://doi. org/10.1111/j.1365-2656.2010.01740.x

Hénaux, V., L. A. Powell, M. P. Vrtiska, and K. A. Hobson. 2012. Establishing winter origins of migrating lesser snow geese using stable isotopes. Avian Conservation and Ecology 7 (1):5. https:// doi.org/10.5751/ACE-00515-070105

Hobaugh, W. C. 1985. Body condition and nutrition of snow geese wintering in southeastern Texas. Journal of Wildlife Management 49:1028-1037. https://doi.org/10.2307/3801390

Hobson, K. A. 1999. Tracing origins and migration of wildlife using stable isotopes: A review. Oecologia 120:314-326. https:// doi.org/10.1007/s004420050865

Hobson, K. A., R. B. Brua, W. L. Hohman, and L. I. Wassenaar. 2000. Low frequency of "double molt" of remiges in Ruddy Ducks revealed by stable isotopes: Implications for tracking migratory waterfowl. The Auk 117:129-135. https://doi.org/10.1093/ auk/117.1.129

Hobson, K. A., S. L. Van Wilgenburg, L. I. Wassenaar, and K. Larson. 2012. Linking Hydrogen $\left(\delta^{2} \mathrm{H}\right)$ Isotopes in Feathers and Precipitation: Sources of Variance and Consequences for Assignment to Isoscapes. PLoS ONE 7:1-9. https://doi.org/ https://doi.org/10.1371/journal.pone.0035137

James, G., D. Witten, T. Hastie, and R. Tibshirani. 2013. An introduction to statistical learning. Volume 112. Springer, New York, New York. https://doi.org/10.1007/978-1-4614-7138-7

Jenni, L., and S. Jenni-eiermann. 1998. Fuel Supply and Metabolic Constraints in Migrating Birds. Journal of Avian Biology 29:521-528. https://doi.org/10.2307/3677171

Jónsson, J. E. 2005. Effects of body size and habitat use on goose behavior: Lesser snow goose and Ross's goose. $\mathrm{PhD}$ thesis. Louisiana State University.

Jónsson, J. E., and A. D. Afton. 2006. Different time and energy budgets of Lesser Snow Geese in rice-prairies and coastal marshes in southwest Louisiana. Waterbirds 29:451-458. https://doi. org/10.1675/1524-4695(2006)29[451:DTAEBO]2.0.CO;2

Jónsson, J. E., M. Frederiksen, and A. D. Afton. 2014. Movements and survival of Lesser Snow Geese (Chen caerulescens caerulescens) wintering in two habitats along the Gulf Coast, Louisiana. Wildfowl 64:54-74.

Kruse, K. L., and D. Fronczak. 2014. Light geese in the Central and Mississippi Flyways. Updated for 2012-2013 harvest and Conservation Order take. U. S. Fish and Wildlife Service, Denver, Colorado, USA. Unpublished report.

Laurance, W. F., J. Sayer, and K. G. Cassman. 2014. Agricultural expansion and its impacts on tropical nature. Trends in Ecology \& Evolution 29:107-116. https://doi.org/10.1016/j.tree.2013.12.001 
Leafloor, J. O., T. J. Moser, and B. Batt. 2012. Evaluation of special management measures for midcontinent lesser snow geese and Ross's geese. Arctic Goose Joint Venture Special Publication. Washington, D.C, Ottawa, Ontario.

Lindström, Å. 1991. Maximum fat deposition rates in migrating birds. Ornis Scandinavica 22:12-19. https://doi.org/10.2307/3676616

Lott, C. A., T. D. Meehan, and J. A. Heath. 2003. Estimating the latitudinal origins of migratory birds using hydrogen and sulfur stable isotopes in feathers: influence of marine prey base. Oecologia 134:505-510. https://doi.org/10.1007/s00442-002-1153-8

Massey, E. R., L. G. Carlson, and D. C. Osborne. 2020. Temporal Trends in Body Condition of Arctic Geese Wintering in the Mississippi Alluvial Valley. Journal of Fish and Wildlife Management 11. https://doi.org/10.3996/062018-JFWM-047

McWilliams, S. R., C. Guglielmo, B. Pierce, and M. Klaassen. 2004. Flying, fasting, and feeding in birds during migration: A nutritional and physiological ecology perspective. Journal of Avian Biology 35:377-393. https://doi.org/10.1111/j.0908-8857.2004.03378. $\mathrm{x}$

Morrison, R. I., N. C. Davidson, and J. R. Wilson. 2007. Survival of the fattest: body stores on migration and survival in red knots Calidris canutus islandica. Journal of Avian Biology 38:479-487. https://doi.org/10.1111/j.0908-8857.2007.03934.x

Nakagawa, S., and H. Schielzeth. 2013. A general and simple method for obtaining R2 from generalized linear mixed-effects models. Methods in Ecology and Evolution 4:133-142. https://doi. org/10.1111/j.2041-210x.2012.00261.x

Norris, D. R. 2005. Carry-over effects and habitat quality in migratory populations. Oikos 109:178-186. https://doi.org/10.1111/ j.0030-1299.2005.13671.x

Peterson, B. J., and B. Fry. 1987. Stable isotopes in ecosystem studies. Annual review of ecology and systematics 18:293-320. https://doi.org/10.1146/annurev.es.18.110187.001453

Schaub, M., L. Jenni, and F. Bairlein. 2008. Fuel stores, fuel accumulation, and the decision to depart from a migration stopover site. Behavioral Ecology 19:657-666. https://doi. org/10.1093/beheco/arn023

Sedinger, J. S., and R. T. Alisauskas. 2014. Cross-seasonal effects and the dynamics of waterfowl populations. Wildfowl 4:277-304.

Sedinger, J. S., J. L. Schamber, D. H. Ward, C. A. Nicolai, and B. Conant. 2011. Carryover effects associated with winter location affect fitness, social status, and population dynamics in a longdistance migrant. The American Naturalist 178:E110-E123. https://doi.org/10.1086/662165
Stanton, R. L., C. A. Morrissey, and R. G. Clark. 2018. Analysis of trends and agricultural drivers of farmland bird declines in North America: A review. Agriculture, Ecosystems \& Environment 254:244-254. https://doi.org/10.1016/j.agee.2017.11.028

Stavert, J. R., D. E. Pattemore, I. Bartomeus, A. C. Gaskett, and J. R. Beggs. 2018. Exotic flies maintain pollination services as native pollinators decline with agricultural expansion. Journal of Applied Ecology 55:1737-1746. https://doi.org/10.1111/1365-2664.13103

[USDA] U.S. Department of Agriculture. 2016. CropScape. National Agriculture Statistics Service. [online] URL: https:// nassgeodata.gmu.edu/CropScape/.

Venables, W. N., and B. D. Ripley. 2002. Modern Applied Statistics with S. Springer-Verlag. New York. https://doi.org/10.1007/978-0-387-21706-2

Warnock, N. 2010. Stopping vs. staging: the difference between a hop and a jump. Journal of Avian Biology 41:621-626. https://doi. org/10.1111/j.1600-048X.2010.05155.X

Webb, E. B., L. M. Smith, M. P. Vrtiska, and T. G. Lagrange. 2010. Effects of local and landscape variables on wetland bird habitat use during migration through the Rainwater Basin. Journal of Wildlife Management 74:109-119. https://doi. org/10.2193/2008-577

Webster, M. S., P. P. Marra, S. M. Haig, S. Bensch, and R. T. Holmes. 2002. Links between worlds: unraveling migratory connectivity. Trends in Ecology \& Evolution 17:76-83. https://doi. org/10.1016/S0169-5347(01)02380-1

Werner, S. J., K. A. Hobson, S. L. Van Wilgenburg, and J. W. Fischer. 2016. Multi-isotopic $\left(\delta^{2} \mathrm{H}, \delta^{13} \mathrm{C}, \delta^{15} \mathrm{~N}\right)$ tracing of molt origin for red-winged blackbirds associated with agro-ecosystems. PLoS ONE 11(11): e0165996. https://doi.org/https://doi. org/10.1371/journal.pone.0165996

Werner, S. J., J. W. Fischer, and K.A. Hobson. 2020. MultiIsotopic $\left(\delta^{2} \mathrm{H}, \delta^{13} \mathrm{C}, \delta^{15} \mathrm{~N}\right)$ tracing of molt origin for European Starlings associated with U.S. dairies and feedlots. PLOS ONE 15 (8):e0237137. https://doi.org/https://doi.org/10.1371/journal.pone.0237137

Wilson, S., R. T. Alisauskas, and D. K. Kellett. 2016. Factors influencing emigration of Ross's and snow geese from an Arctic breeding area. Journal of Wildlife Management 80:117-126. https://doi.org/10.1002/jwmg.960

Wretenberg, J., Å. Lindström, S. Svensson, T. Thierfelder, and T. Pärt. 2006. Population trends of farmland birds in Sweden and England: similar trends but different patterns of agricultural intensification. Journal of Applied Ecology 43:1110-1120. https:// doi.org/10.1111/j.1365-2664.2006.01216.x
Editor-in-Chief: Alexander L.Bond Subject Editor: Jean-Pierre L.Savard

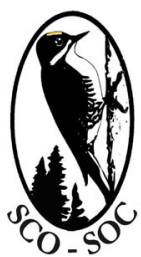

Sponsored by the Society of Canadian Ornithologists and Birds Canada

Parrainée par la Société des ornithologistes du Canada et Oiseaux Canada

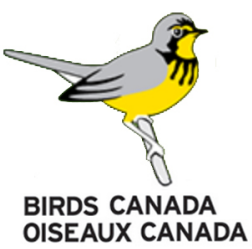

